\title{
Interrogating the Geographies of the Familiar: Domesticating Nature and Constructing the Autonomy of the Modern Home*
}

\author{
MARIA KAIKA
}

\section{The modern home as the dwelling space of individual freedom}

This is the true nature of home - it is the place of peace: the shelter not only from all injury, but from all terror, doubt and division. In so far as it is not this, it is not home; so far as the anxieties of the outer life penetrate into it, and the inconsistently-minded, unloved, or hostile society of the outer world is allowed by either husband or wife to cross the threshold, it ceases to be a home; it is then only a part of the outer world, which you have roofed over and lighted fire in (John Ruskin, 1891 'Sesame and Lilies' 136-37, cited in Sennett 1990: 20).

The idea of the house as a means of separating the inside from the outside, nature from human beings, the public from the private sphere, has existed since antiquity. For Heidegger, the house is understood 'as the most primitive drawing of a line that produces an inside opposed to an outside' (cited in Wigley, 1996: 104). The debate as to whether this line is (or should be) rigid and unsurpassable, or indeed, as to whether it should exist at all, also goes back to antiquity. In Plato's (360 BC) Republic (1992) the polis, the public sphere, is defined as the opposite to the private sphere, only for this statement to be frustrated later on in the same dialogue by mentioning certain Athenians who insisted on performing private activities (washing, sleeping, etc.) in public. Plato, again, in his Statesman (1995) juxtaposed critically the public sphere of the agora to the private sphere of the household (oikos) and argued that both realms are eligible for political praxis. However, from the Enlightenment onwards, the production of the modern (bourgeois) house as an isolated and a-political space and separate from the public sphere, was understood as a particularly positive development in the western world. As the opening quote by Ruskin demonstrates, the right to a private space became closely linked to the idea of individual freedom (of the white western male subject) that constituted the core of Enlightenment thinking, and access to an isolated private sphere became part of a broader social project of emancipation (Gay, 1973). ${ }^{1}$ Whilst individual freedom became the sacred principle of the modernizing western world, the individualized space of the private house became its sacred space (Sennett, 1990). The house - a material construction, an edifice - became socially constructed

\footnotetext{
* I would like to thank the editors and the anonymous referees for their valuable comments. Many thanks also to Erik Swyngedouw and David Dodman for their comments on earlier versions of the article and to George Shoterioo for the photographs. Special thanks to the Guildhall Library (especially $\mathrm{Mr}$ Jeremy Smith), photographer Erwin Olaf, M\&C Saatchi (especially Mr Ian Allister) and Editions PEMF, France, for kindly providing copyright permissions for the images.
}

1 As many feminist theorists showed, struggles for access to a sheltered private space as a means of emancipation targeted the white western male subject alone. The article elaborates further on this idea later on. 
as the home - a place imbued with cultural and ideological meaning. The dwelling space of the modern (bourgeois) individual became constructed not only as a line separating the inside from the outside (a house), but also as the epitome, the spatial inscription of the idea of individual freedom, a place liberated from fear and anxiety, a place supposedly untouched by social, political and natural processes, a place enjoying an autonomous and independent existence: a home. In the opening quote of this article, Ruskin offers a definition of the 'true nature of home', by singling out two basic qualities that a house should possess in order to become a home. Both qualities have to do with the capacity of the edifice to keep outside:

1 Social processes and social relations (crime, socially excluded groups, homelessness, undesired others, etc.); but, also

2 Natural processes and natural elements (dust, cold or polluted air, rain, dirt, sewage, smog, etc.)

According to Ruskin, the modern house becomes the modern home (an autonomous protected utopia) through a dual practice of exclusion: through ostracizing the undesired social as well as the undesired natural elements and processes. The social and spatial implications of the exclusion of social processes have been analysed and detailed in numerous studies in geography, architecture, anthropology and sociology. ${ }^{2}$ However, the socio-spatial implications of the exclusion of nature and natural processes has not been adequately researched or documented. Katz (1998) as well as Braun and Castree (1998) argue that, despite the intense study of the nature/society separation in academic literature, a systematic analysis of the spatial implications of this separation is yet to be undertaken. This article attempts such an analysis. Informed by recent studies on the dualism between nature and society (Smith, 1984; Bird, 1987; Fitzimmons, 1989; Katz and Kirby, 1991; Latour, 1993; Simmons, 1993; Castree, 1995; Harvey, 1996), the article investigates the spatial implications of this dualism with respect to the construction of the modern home as an autonomous entity. It does so by assessing the material versus the ideologically constructed boundaries between 'the natural' and 'the domestic' space.

The article examines the historical geographical process through which nature became scripted as 'the other' to the private space of the bourgeois home in western societies. Using one natural element, water, as a vehicle, it investigates how this particular form of alienation contributed to the conceptual construction of the home as a space autonomous and independent from socio-natural processes, as a distinct and autonomous 'space envelope' (Lefebvre, 1968). Secondly, the ideological/conceptual construction of the home as independent from nature and society is contrasted with the heavy dependence of the material construction of the same space on social and natural processes. By reconstructing the invisible material and social continuity that exists between the production of nature and the production of the modern home, it is shown that, although natural and social processes remain invisible and are scripted as 'the other' to the modern home, they are in fact the precondition for the home's very existence and remain always part and parcel of its inside. Finally, the article argues that this simultaneous act of need and denial of the connection of the home to socio-natural processes turns the material manifestations (networks, pipes, etc.) of this connection into the domestic uncanny that surfaces during moments of crisis. At these moments, the continuity of the social and material processes that produce the domestic space is unexpectedly foregrounded, bringing the dweller of the modern home face to face with his/her alienation. The article concludes by indicating the possibilities for emancipation that arise from the exposure of the alienation of the modern individual within his/her own dwelling space.

2 Massey (1984), Harvey and Chatterjee (1973), Sennett (1990), Jacobs (1961), Vidler (1992) and Wigley (1996), amongst many others, study the political, economic and cultural processes behind the separation between private/public spaces and the ideological grounds of the supposed autonomy of the modern home from social processes. 


\section{Scripting natural processes as 'the other': good versus bad nature}

Modernity emerges from the belief that man is fundamentally a clean body (Lahiji and Friedman, 1997).

In recent studies, the theoretically investigated and empirically documented understanding that there is no pristine nature 'out there' was coupled with attempts to reconceptualize the nature/society relationship (Smith, 1984; Castree, 1995; Harvey, 1996). The introduction of the notions of the 'hybrid' in Donna Haraway's work (1991), or the 'quasi object' by Bruno Latour (1993), theorized modernity's production of objects which are neither purely natural nor purely human constructions, and offered insightful ways to analyse further the nature/society dualism. Water provides an excellent example of such a 'quasi-object': something that is, on the one hand, materially produced as a hybrid and as a commodity (and thus subject to social relations of production) but on the other hand is socially constructed as part of nature (and thus supposedly alien to social processes). This section investigates the social and spatial implications of this contradiction.

Water, like other natural elements (gas, petrol, etc.), is produced, purified, standardized and commodified. As water is abstracted, dammed, channelled, stored, distilled and chlorinated, its physical and social qualities change as it inevitably becomes subject to social relations of production. It becomes a 'hybrid': neither purely 'natural' nor purely a 'human product' (Swyngedouw and Kaika, 2000). In addition, the flow of produced water (along with other forms of produced nature) becomes part and parcel of the material construction of the modern home. The modern home cannot function without adequate supply of water: to drink, bathe, clean and drain. Ironically, however, whilst nature becomes essential for the construction of the modern home, it becomes simultaneously discursively constructed as separate, as 'the other' to the private space of home, as in Ruskin's quote. In order to investigate this contradiction and its socio-spatial implications, I shall follow the flow of water and discuss how this element undergoes a production process which transforms not only $\mathrm{H}_{2} \mathrm{O}$ itself, but also the spaces through which it moves.

In the western world, water was traditionally searched for outside the house, often outside the settlement area, and brought into the house through painstaking efforts, predominantly carried out on the part of women, practices still found in non-western societies (Curtis, 1986; Cleaver and Elson, 1995). However, through a historically and geographically specific process of domestication and commodification (which is part and parcel of western industrialization and urbanization) access to water in the western world has been made as easy and simple as turning a tap inside the private space of one's home. The domestication of water changed the traditional places where this element can be found. As water travels through a myriad of intricate physical sociospatial networks (channels, reservoirs, pipes, taps) from spaces of production (dams, wells, reservoirs, pumping stations, purifying stations,) to spaces of consumption/ reproduction (city, home), it is not only its physical and social qualities that change, but also its relationship to space. Water's dwelling space shifts geographically from the countryside (rivers, lakes, boreholes) to the city (public ornamental and drinking fountains) and finally to the house (taps, baths, private swimming pools, private ornamental fountains, ponds). Although the incorporation of urban water into the economic mode of production had been taking place since medieval times (Thacker, 1968, cited in Oliver, 2000), the most far-reaching changes in the character, treatment and spaces of water took place during the nineteenth and early twentieth century. During that period, the increasing incorporation of water into the economic and social life of expanding urban areas, combined with the discovery of the link between water and epidemics, generated a science, economy and practice of treating and purifying water. This practice led to the material production of purified drinking water as a new modern hybrid; and to the discursive construction of two distinct 'types' of water: good water (clean, processed, controlled, commodified) and bad water (dirty, grey, 


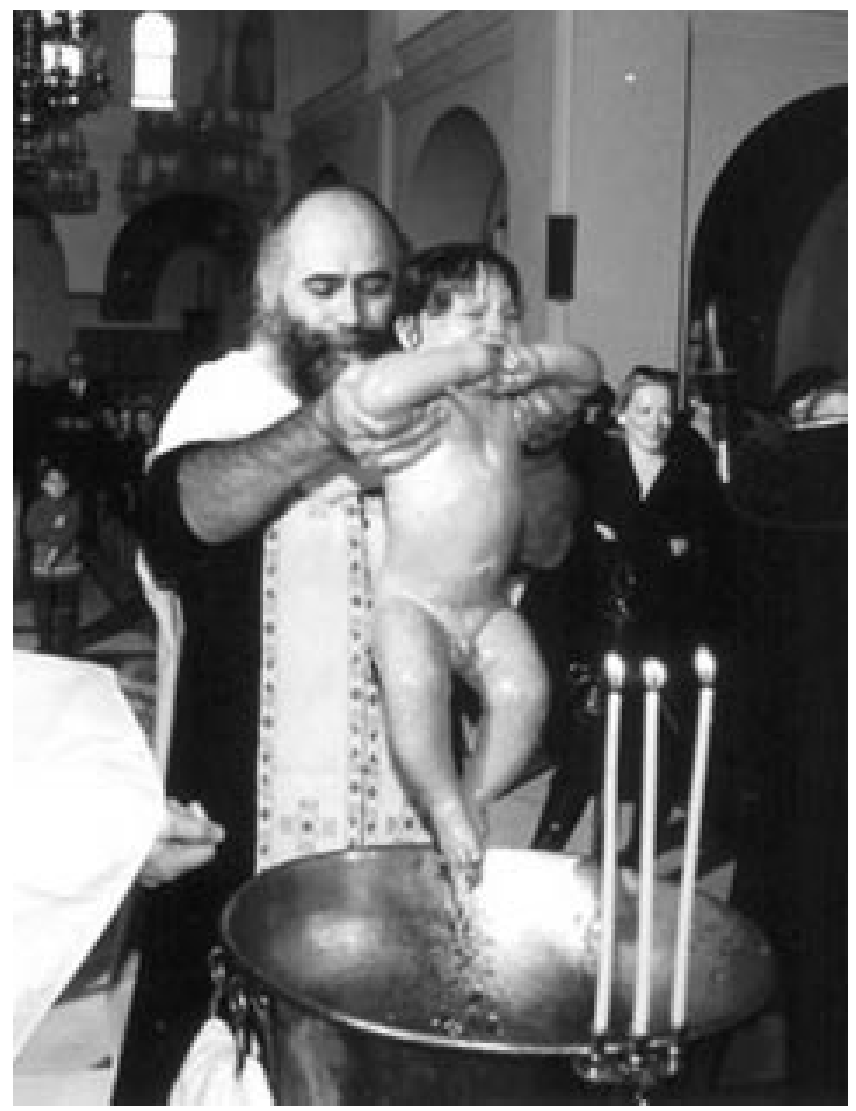

Figure 1 Good water: immersing the baby in holy water at a Christian Orthodox Baptism (photograph: George Shoterioo)

metabolized, non-processed, non-commodified). The first category includes water for drinking, bathing, swimming, baptising, etc., while the second comprises untreated metabolized water, to be found in city rivers, lakes, rainwater, sewerage, etc. It was therefore established that before water is allowed to make contact with the human body, it has to be controlled and mastered, processed and produced, like almost every other form of nature (Foucault, 1977). While contact with bad water was considered to be deleterious, if not harmful, to the human body, good water became the cleansing, purifying, healthy element (Figures 1 and 2).

The material and discursive production of two distinct kinds of water meant that access to water became mediated by increasingly complex social and material relations umpired by the market. The changes in the physical and social character of water went hand in glove with the creation and allocation of specific spaces for the use of good and bad water. A set of new spaces ${ }^{3}$ — such as swimming pools, spas and private bathrooms - were created and specially allocated to the interaction between the human body and good water. Getting in touch with water in the form of bathing in a bathtub, swimming in the newly devised and constructed temples for swimming, or purifying mind and body in the middle-class's favourite spas was considered to be a safe and sanitizing activity. In contrast, getting in touch with water in an uncontrolled and unregulated manner — swimming in rivers and lakes, getting wet in the rain, or drinking untreated water - became a negative and potentially harmful activity. 


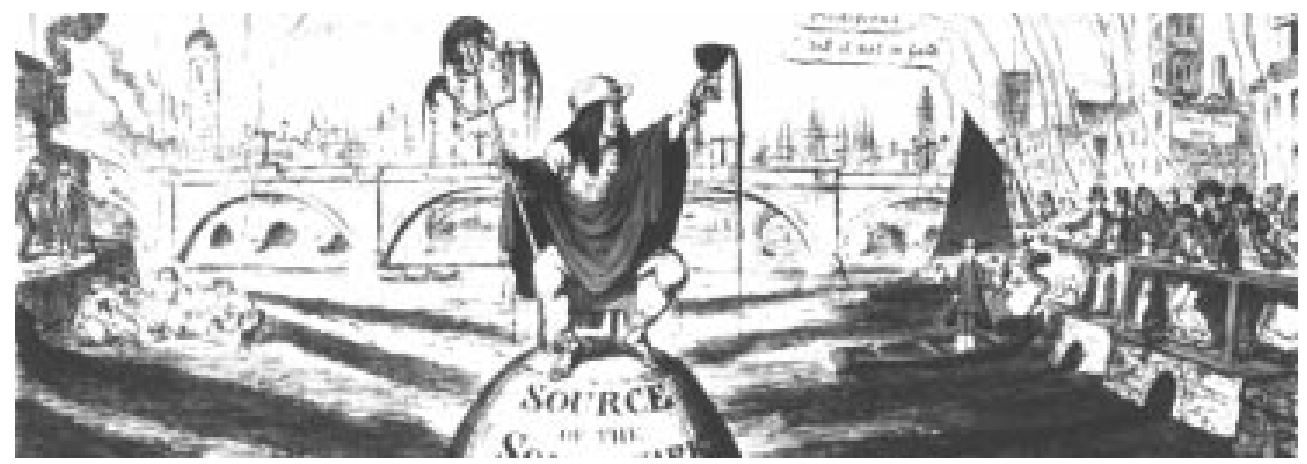

Figure 2 Bad water: John Edwards, owner of Southwark Water Works, sitting in the middle of a heavily polluted Thames river, while Southwark residents shout complaints ('Salus populi suprema lex' etching by George Cruikshank, 1832; reproduction courtesy of The Guildhall Library, Satirical Print collection London Archive, record no. 20319)

Thus, while water in the city became a source of threat, and thus something to be controlled or eradicated from the cityscape, water in the house became exactly the opposite: the purifying, cleansing element, proudly displayed by the middle classes who could afford to have it running inside their home. The hydrophobia developed towards the uncontrolled waters of the public (urban) domain, was paralleled by a hydrophilia towards the controlled waters of the private space of one's home (Chappells et al., 1999), which by the late nineteenth century included its designated 'wet rooms' (i.e. bathroom and kitchen) as indicators of social status (Lupton and Miller, 1996). In Britain, middle-class houses began to feature private bathrooms from the $1880 \mathrm{~s}$, and by the 1930s, they had become a common feature of working-class houses too (Forty, 1995: 166-7). In Paris, the bourgeoisie started installing private bathrooms in the first decades of the nineteenth century. After 1850 the new 'bathing institutions' appeared in the popular quarters of the city, while by the mid-twentieth century the distribution of water in private houses became a common feature (Buisson, 1991). In Athens, by 1928 all new apartment buildings were being built with a fitted bathroom, offering the delights and pleasures of domestic water supply to the emerging middle classes (Gerontas and Skouzes, 1963). In the United States, 93.5\% of urban dwellings had running water by 1940 (Lupton and Miller, 1996: 23).

As availability of and access to commodified water increased in the domestic sphere, availability of good (e.g. drinking) water in the public sphere became confined to the past in the western world. Public fountains, for example, slowly disappeared from the urban domain in the western world, corresponding to the reconceptualization of water as a commodity, while they still remain an integral part of urban life in the Islamic world, corresponding to the Islamic law defining water as the undeniable right of people and animals alike (Wescoat, 1995). Indeed, in western metropolises publicly available free of charge clean drinking water is a rare species. The simple ethnographic test of walking into any coffee/sandwich bar in London asking for a free glass of (tap) water, invariably results in a frown and a perplexed look followed by: "we only sell bottled water'. Until recently, on some European flights one could not get a glass of water unless one were prepared to pay for it, whilst nightclub owners would block the cold taps in the bathrooms to prevent patrons from drinking 'free' water. This latter practice has only been made illegal in the light of people dying from dehydration after taking ecstasy tablets. ${ }^{4}$

Along with publicly available good drinking water, uncontrolled, dirty bad water was also slowly but steadily eradicated from the visible urban domain. In London

4 See The Observer (20 January 2002). In January 2003, free water availability was made a legal requirement by the US Department of Gaming and Racing (The Sunday Morning Herald, 2 January 2003). 
during the nineteenth century, ${ }^{5}$ for example, over a dozen rivers were covered by streets in an effort to rationalize urban space and to eliminate the threat of epidemics (Halliday, 1999). All European and most North American cities experienced a similar process (see Keil, 1998; Latour and Hermant, 1998). In sum, the bourgeois home became the 'natural' space to look for 'freely' flowing good water and a conceptual distinction, if not separation, was generated between the urban as the place where bad water dwells (together with other urban anomies) and the protected space of the home where good water emerges in its commodified form. Good nature (purified water, conditioned air, electricity, etc.) became part of (and a basic precondition for the construction of) the protected inside of the modern home. At the same time, the domestically metabolized bad nature (dirty water, polluted air, sewage) became part of the outside, 'the other', the antipode to the comfortable, protected inside of the home. Thus, while modernity produced nature as a commodity and made it an intrinsic part of modern life, it simultaneously conceptually constructed nature as an externalized 'other' (Bauman, 1991) for which 'socially constructed places' were created (Oliver, 2000: 227). This double process of casting processed nature outside the modern home, while allowing controlled commodified nature inside, reinforced the ideological construction of the private sphere as the utopia of the autonomous and the protected, and of the modern private individual as clean, pure, and free of fear and anxiety.

The conceptual distinction between good and bad water also perpetuated (and in many ways accentuated) the gender distinction related to its handling. Using water in the household had traditionally been the task of women (Hill, 1972), whereas handling and taming water outside the house (from field irrigation to dam construction and the conquest of the sea) was traditionally the task of men (Kendie, 1996). From washing the floor to cleaning the dead (Illich, 1986), women's perceived 'deep connection to nature' had given them jurisdiction over handling water in the domestic sphere (Shiva, 1997). Women's traditional task of collecting water for domestic use from wells or springs was (still is in many parts of the world) an extra burden on their already heavy daily schedule but it also produced a predominantly female domain around the well, the public fountain or the river, and, in many cases, provided one of the few opportunities for women to socialize freely. However, when water was domesticated in the western world, the traditional gender distinction around handling water did not change: it was again the 'wet rooms' of the bourgeois home that became the place of women in the domestic spatial arrangements that accompanied the social division of labour, thus endorsing the confinement of women to the domestic sphere (Seager, 1997). Indeed, kitchens and bathrooms are often depicted in modern (western) art and literature as the 'kingdom' of women, as the ritual of handling water and cleaning the home remains one of the few domains where women's judgment and expertise remains unquestioned.

Never before had a woman worshipped her home the way I worshipped mine. My grandmother used to say: "I like cleaning my home by myself". ... Just like my grandmother used to do, I threw away the mop pole and fell down on my knees to mop the floor with my own palms, with devotion. And while mopping I was caressing it [the floor] ... the way a mother would caress her ill child (Maria Iordanidou, 1987, 'The twirling of the circle': 36, author's translation).

The above passage comes from a semi-autobiographical late twentieth-century novel written by a woman and set in post-war Athens. The narrator, a woman who works hard to support her family, takes both pride and pleasure in making time to clean her home. In an almost perverse manner, cleaning her home becomes an act of worship as it becomes identified with caring for her family. The 'elevated status of housekeeping' (Rose, 1993: 121) expressed in the identification of an act of worship with that of cleaning one's home has even permeated the language. In the original Greek text, the

5 Although for two of them, the Walbrook and the Fleet, the covering began much earlier, in 1463 and 1732 respectively (Halliday, 1999). 


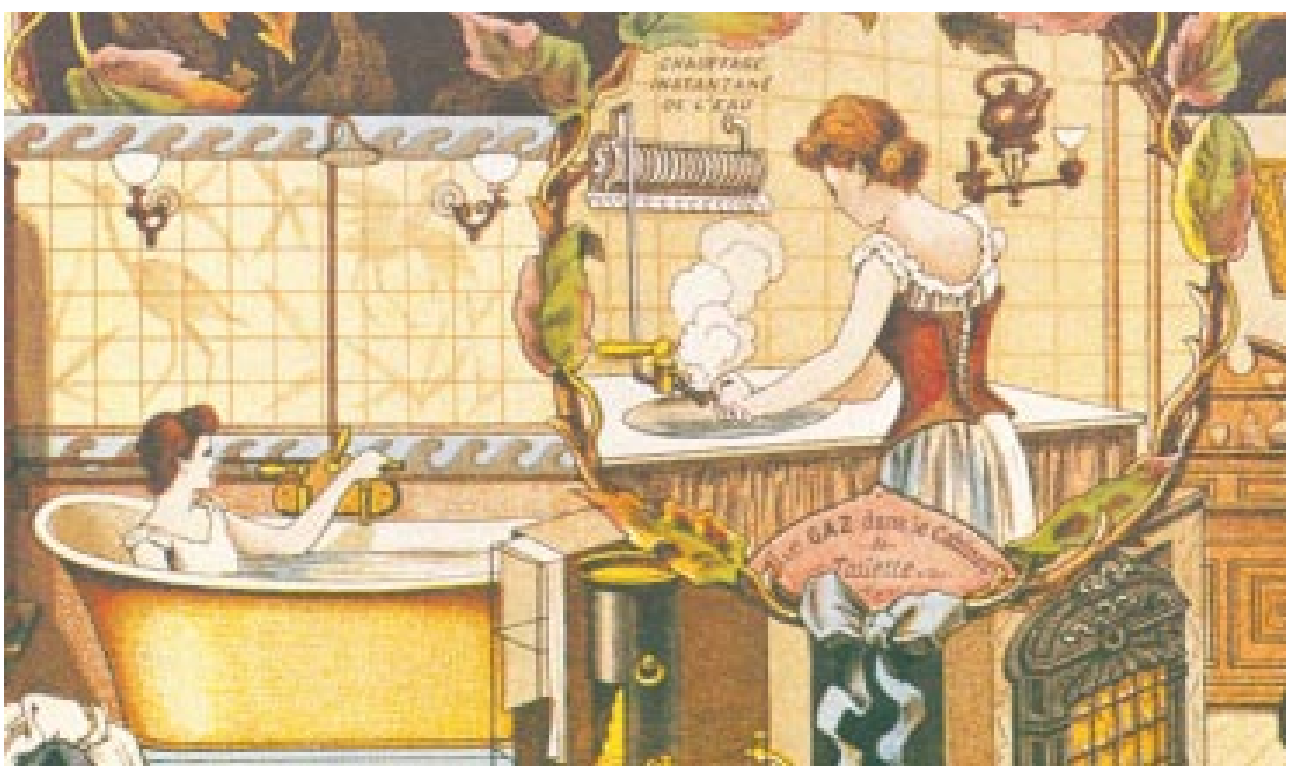

Figure 3 Illustrating the intimate relationship between women and domesticated water (from an 1892 French calendar, published in Périscope, L'Usage domestique de l'eau, (C) PEMF, France; reproduction courtesy of Editions PEMF)

word ' $\lambda \alpha \tau \rho \epsilon \nu$ ' $\omega$ ' signifies both 'to worship' and 'to clean'. Thus, the first sentence can be translated as either: 'Never before had a woman worshipped her home the way I worshipped mine'; or: 'Never before had a woman cleaned her home the way I cleaned mine'. Thus, the act of worshipping one's home (and family) collapses linguistically with that of cleaning one's home, indicating the extent to which the role of women as home cleaners and water handlers is socially and culturally embedded (Pollock, 1988; Young, 1990).

However, it is always good water alone that becomes women's and it does so only after it enters the protected 'space envelope' of the domestic sphere (Figure 3). In contrast, the process of taming bad water as well as that of producing good water - the construction of dams, wells, aqueducts, the irrigation of fields, etc. - remains predominantly the task of men (McDowell, 1983; Rose, 1993). In short, the gender division between places and activities of production and reproduction (Hayford, 1974) was itself reproduced through the process of domestication of water in the western world.

The control of nature's water also contributed to the production of the new set of marks of social distinction that could be embodied by the modern individual. As Swyngedouw (1997) contends, the olfactorial segregation between class and gender (rich smelling clean/poor smelling foul; women smelling of roses, men smelling of tobacco) was made easier with the domestication of water (see also Pratt, 1990). As Sibley (1992) argues, the social imperative to distinguish between good and bad, pure and impure became carried by the body itself, by the skin, the epidermis. If, however, we were to elaborate further on Sibley's analysis, we could argue that this epidermalization first has to be materially produced. In order for the body, for the epidermis, to be able to carry the socially constructed marker of pure/impure, perfumed/ malodorous, a whole set of material connections have to be laid in place and maintained. The body remains the carrier of the symbolic marks of social distinction, but space (such as underground urban space) is the carrier of the material constructions and connections that make this symbolic distinction possible. Thus, the separation of the city and the home as two of modernity's distinct 'spatial envelopes', is not just an expression of epidermalized distinction of social status; it is one of the very mechanisms that enables this distinction to exist. This makes space more than just a 
parameter in the social construction of the body (Grosz, 1995; Pile, 1996). The dwelling places of modernity embody the material connections that make the social construction of bodies possible, by first materially constructing 'others', in the form of natural or social processes, and then keeping them outside.

\section{Keeping 'the other' outside: exclusion as an act of creating space}

The 'elements' lose their natural determinations, including their siting and situation, as they are incorporated into the 'space envelopes' which are fast becoming the social buildingblocks of space (Lefebvre, 1974: 329).

The previous section examined the socio-spatial processes through which water and the social relations involved in its production became 'the other' to the private space of home. This section examines how the exclusion of this 'other' (in the form of natural or social processes) is in fact central to creating the sense of familiarity, safety and isolation inside the modern home. In other words, how this act of exclusion becomes an act of creating space — the private, isolated space of the home - (Wigley, 1996: 105) and how it contributes to the conceptual construction of nature and the home as distinct and autonomous 'space envelopes', as Lefebvre (1974) put it.

In the opening quote of this article, Ruskin defines the 'true nature of home' as 'a shelter from anomie and division'. Dirt, fear and anxiety stemming from social and natural processes are supposed to have been 'exiled' from this isolated private space and confined instead (if not relegated) to the urban space or to nature. Thus, excluding socio-natural processes as 'the other' becomes a prerequisite for the construction of the familiar space of the home. The inside becomes safe, familiar and independent not only by excluding rain, cold and pollution, but also through keeping fear, anxiety, social upheaval and inequality outside.

Of course, the practice of keeping natural elements outside the home is not particularly new; but rather goes hand in glove with the whole history and raison d' etre of architecture. The purpose of building a home through human history has been precisely that: to create a familiar environment ${ }^{6}$ by establishing a high level of control over the interaction between the edifice and its environment; to construct an inside in opposition to an existing outside. However, what distinguishes the modern home from earlier forms of 'dwellings' is that never before has the level of control over the outside been so high or achieved so fully as in modern buildings. Producing a spatial outlet for Enlightenment ideas, modernist planning and building launched a crusade to impose clarity between functions, to distinguish between private and public space and to separate nature from the built environment. It did so by establishing practices of control and networks of distribution of both produced nature and social relations. Epitomizing this attitude, the famous Charter of Athens, that came out of the IV Congrès International d'Árchitecture Moderne (CIAM) (Le Corbusier and Giraudoux, 1933) depicted home, work, recreation and traffic as distinct components of modern living, while asserting the need to engage with technological innovation. To this end, the laying down of a sophisticated set of networks for the flow of socio-natural processes (water, sewage, electricity, gas, etc.), was complemented by the laying down of a set of rules for the flow of socio-economic processes (zoning of urban functions and land use, movement of pedestrians and vehicles, distinction between places of production, reproduction and recreation, etc.). Technological advancement (plumbing, central heating, air conditioning, etc.) made the exclusion and control of natural elements more efficient and sophisticated than ever before, securing that the modern home would function safely, securely and autonomously. Unwelcome social and natural elements (from sewage to homelessness) were exiled underneath or outside the modern home,

6 The ancient Greek word for house/dwelling space oíкoৎ (oikoôs) has the same root as the word for the familiar olkcío (oikêïoôs) (see also Derrida, 1987). 
below the streets and inside the walls, eliminated into underground passages, sent to a domain separate to that of the dwelling places of the modern individual. To do justice to modernist planning, it should be noted that its original aims were linked to social struggles for creating spaces that would act as a shelter away from the alienation of waged labour (Mackenzie and Rose, 1983). Nevertheless, practices of modernist planning failed to 'open up' space for everybody through the creation of safe private and public spaces. Instead, they succeeded in rendering the line that separates the inside from the outside, the public from the private, more solid than ever before, virtually impenetrable, at least at a discursive and representational level. A sublime visualization of this contradiction within modernity's creative destruction are Giovanni Battista Piranesi's (1720-78) Carceri drawings. They are an early harbinger and a gothic representation of a modern world which opens up space and potentials for emancipation, only to re-close it again and to alienate its dwellers-inmates. According to Tafuri, Piranesi's drawings are expressions of 'the new existential condition of human collectivity, liberated and condemned at the same time by its own reason' (Tafuri, 1973: 18).

When we move from the discursive/representational level to the material/spatial foundations of the separation between public/private, nature/home, it can be argued that this same act of exclusion that separates and demarcates the inside from the outside, in fact puts these two supposed 'opposites' in a dialectical relationship of interdependence to each other, within which they are both sustained and continue to function. Whilst the inside (the familiar) needs the outside (the unfamiliar) to construct and define itself as a distinct space, the excluded outside in turn functions by following the logic of the inside. In doing so, the outside always remains in a certain way inside, subject to the rules and the logic dictated by the inside (Faust et al., 1992): there can be no homelessness without an economic, political and social process that produces 'the home' as a commodity; no refugees without practices of exile from a 'country of origin'; no margin without a centre; no periphery without a core. As Wigley put it: 'by being placed outside, the other is placed, domesticated, kept inside. To be excluded is to be subjected to a certain domestic violence' (1996: 107; see also Derrida, 1981).

\section{The selective porosity of the modern home: a simultaneous act of need and denial of 'the other'}

\section{Social processes: reproducing exclusion}

The exclusion of social processes is, according to Ruskin, the first basic precondition for the production of the modern home. However, this section will explore how the very act of trying to keep social processes outside inevitably puts this space (the home) into a dialectical relationship of dependence on/autonomy from the very processes that it tries to exclude. To start with, the material creation of an isolated private space, almost by definition puts significant claims on social (i.e. public) space. The creation of protected, privately policed and guarded domestic spaces depends upon the appropriation (and, in effect, destruction) of public (social) space, which becomes 'privatized'. Davis (1992) presents the city as a continuous alternation between utopias of private, policed green areas and dystopias of public areas or areas housing the socially excluded (see also Merrifield, 2000). Deutsche (1996) dwells on the same dialectic between private/public, exclusion/inclusion and records how homelessness is cast out of practices of exclusion; the 'marginal' places claimed by the homeless are what is 'left-over' from the process of carving out places for the private sphere. Spatial claims made by the private sphere (domestic or other) are always translated into the deprivation of the public sphere from these same spaces and the reduction of spaces of the margin. Anderson and Jacobs (1999) offer an excellent account of a social movement against private claims over public spaces in Australia, concluding that both public and private space should be understood as socio-spatial constructions, rather than 'natural' categories. 
Thus, contrary to the first of Ruskin's claims, the creation of the private space of the home fails to offer shelter from division, since its very social and material production is predicated precisely upon practices of division. As for providing shelter from anomie (the second of Ruskin's claims), the modern home falls short of offering this as well: not only did it fail to exclude social anomie from its interior; it ended up reproducing fragmentation and inequality inside it. Through the process of division of labour and the allocation of different spaces to different users, stratified by gender, age, status, etc. (Massey, 1984; Sennett, 1990) the social and gender inequalities, power relations and violence that were meant to be kept outside the modern home, are reproduced within the 'ideological prison' (Millett, 1977) of this private space.

\section{Natural processes: a selective elimination and the porosity of the modern home}

The previous section examined the first precondition that Ruskin demarcated as necessary for the construction of the modern home (the exclusion of social processes) and exposed its contradictions. This section will turn to the second precondition (the exclusion of natural processes), in order to suggest that similar contradictions are in place.

To start with, it should be noted that natural elements are not, in fact, kept altogether outside the modern home; but rather are selectively allowed to enter after having undergone significant material and social transformations, through being produced, purified and commodified. Polluted air and recycled water, for example, have to undergo a complex chemical and social process of purification before they are allowed to enter the domestic sphere of consumption. In fact, the more human activities transform nature, the more the intervention of technology (e.g. water purifiers, air conditioning, ionisers) becomes necessary in order to 'cancel' the effects of this transformation and to render nature good again before it is allowed to enter the private home in the form of a commodity. Thus, although excluded ideologically, natural processes (just like social processes) remain connected materially to the inside of the home, constituting an integral part of its material production and its smooth function. Yet, as we have seen, the function of the modern home as safe and autonomous is predicated not only upon the entry of good nature, but also upon the ideological and visual exclusion of bad nature. However, this ostracized bad nature is largely the byproduct of the metabolism of the good nature that is allowed inside: sewage is the byproduct of domestic water consumption; urban smog is the result of the need to produce warmth inside one's home and to commute for miles in order to inhabit the suburban domestic paradises. In fact, both the good nature that enters inside and the bad nature that is kept outside the modern home are socio-natural hybrids, transformed through human economic and social activity, and thus neither purely natural nor purely a human construct (Swyngedouw and Kaika, 2000). Viewed in this light, the socially constructed categories of good and bad nature become blurred. The purified water that flows into the modern home is the product of the interaction between the physical environment and human beings, and so is the water that flows out of the modern home in the form of sewage. The production and flow of both hybrid forms of water depend upon the existence of a complex set of material and social networks.

However, these material and social networks are visually excluded. The pipes and cables involved in the production of nature are kept away from the eyes of the home dweller, buried inside the walls of the modern home or underneath the modern city. Even the once iconic landmarks of modernist planning that Kaika and Swyngedouw (2000) termed the 'urban dowry' of modernity - water towers, dams, pumping stations, power plants, gas stations, etc. - became invisible or banalized in the form of urban ruins. Thus, the function of the modern home as safe and autonomous is predicated not only upon the exclusion of bad nature from its premises, but also upon the visual exclusion of the networks and social relations that produce and transport good nature into the domestic and pump bad nature back into the urban domain (Graham and Marvin, 1996). In short, the material and social networks involved in the production of good nature and in the metabolism of bad nature exist and operate in a way that serves 
the logic of the inside, yet remain invisible, hidden outside and underneath the modern home. In this way, the networks of production of the socio-natural hybrids that enter into and are expelled from the modern home, also constitute the 'other', the 'outside' to this modern institution. Although visually excluded and ideologically denied, these networks of socio-natural transformation that lie at the core of the production of the modern city (Graham and Marvin, 2001) also lie at the core of the production of the safety and familiarity of the modern home.

If, again, the case of domesticated water is used as an example, the above contradiction can be explored further. The presence of good water inside the house is based on the existence of a set of networks of, and connections to, both things (dams, reservoirs, pipes) and social power relations (struggles over the allocation of water, over policies of pricing and privatization) that exist outside the domestic sphere. All of the above elements are visually excluded from the sphere of everyday domestic life, yet they are organized in such a way that allows this inside to function supposedly 'autonomously'. While the dweller experiences the familiarity and comfort of his/her domestic tap, bathtub or swimming pool, the intricate set of networks that produce this bliss remains invisible to him/her, hidden underneath and outside the house. It is precisely this visual exclusion of production networks, of metabolized nature and of social power relations, that contributes greatly to the production of a sense of the familiar inside one's home. In a deceitful way, remaining unfamiliar with the above socio-natural networks is a prerequisite for feeling familiar within one's own home.

Hence, we can detect an interesting parallel between the ideological exclusion of social processes and the ideological exclusion of natural processes from the domestic sphere. In both cases, the sense of familiarity within the modern home is predicated upon its material connection to the very elements and processes which are excluded ideologically. The 'other' in the form of natural processes or social relations of production is simultaneously inside yet outside, domestic yet unfamiliar, homely yet unhomely. Thus, although the modern home is ideologically constructed as independent and disconnected from natural processes, its function is heavily dependent upon its material connections to these very processes which are mediated through a series of networks and social power relations.

In the light of the above argumentation, Heidegger's metaphorical description of the divide between the inside and the outside of the home as a 'line' becomes rather too rigid to express the complex dialectical relation that exists between these two spaces and to capture the ever shifting boundaries between the inside and the outside of the domestic sphere. Perhaps a more pertinent way to describe this line would be to compare it to a porous membrane, a membrane which separates the two spaces, yet still allows significant but controlled interaction between them. This membrane works as a filter which allows certain elements in, while excluding others. Walter Benjamin refers to porosity as 'the lack of clear boundaries between phenomena, a permeation of one thing by another, a merger of, for example old and new, public and private, sacred and profane' (Gilloch, 1996: 25; see also Buck-Morss, 1995). By keeping outside the undesired (most of the time non-commodified) natural and social 'things' and processes, and by welcoming inside the desirable ones (filtered, produced and commodified), the modern home has acquired a selective porosity which is enabled by a set of invisible social and material connections.

Thus, it could be argued that relegating social and natural processes outside the dwelling spaces of modernity - the two cornerstones for producing a home according to Ruskin's vision - are conditions that have been met only at an ideological (representational-visual and discursive-perceptive) level. In fact, both social and natural processes have been hidden rather than ostracized altogether outside the modern home. Representative of modernity's inherent contradictions (Kellner, 1998) the modern home, in a simultaneous act of need and denial, hosts in its guts everything it tries to keep outside. It is its connection to everything it tries to disconnect from, to the invisible material and social relations that lie underneath its visible counterparts, that gives the modern home its air of familiarity and autonomy. In a subversive manner, 
remaining unfamiliar with the socio-natural networks that produce domesticity is a prerequisite for feeling familiar within one's own home.

\section{The threatening geographies of the familiar: the invisible 'other' as the domestic uncanny}

The construction of the familiarity of the domestic sphere as the place of peace, free from division and anomie, but also as the epitome of the familiar, a place free from anxiety and terror is predicated upon keeping the social and material elements that constitute 'the other' invisible and outside. Nevertheless, we have seen that this invisible excluded 'other' is simultaneously needed as an essential part of the construction of the familiarity of the inside.

Yet at times of crisis, hidden elements can surface unexpectedly, and familiar objects can behave in unusual ways. For example, at times of water shortage, taps fail to provide water, and during black outs the flick of a switch no longer results in the instant provision of light. Such moments reveal the presence of the excluded 'outside' as a constitutive part of the 'inside'. A leakage or burst pipe reveals a hidden and intricate system of pipes and water mains; a tap which goes dry due to water shortages or maintenance works refers to the complex network of production and distribution of water; and the accumulation of garbage as a consequence of municipal strikes (Figure 4) forces the public to consider the complex process of waste collection and disposal.

Such incidents produce a feeling of uneasiness, discomfort and anxiety, which threatens to tear down the laboriously built and elaborately maintained security and safety of familiar spaces (Vidler, 2001). These occurrences put the normalized character of the control and commodification of nature into question, and threaten the smooth functioning of the domestic sphere. Such an exposure of the limits of domestic bliss, and a revelation of its dependency on social relations of production generates a feeling of 'not being at home in one's own home' (Vidler, 1992: 4). This unhomely feeling

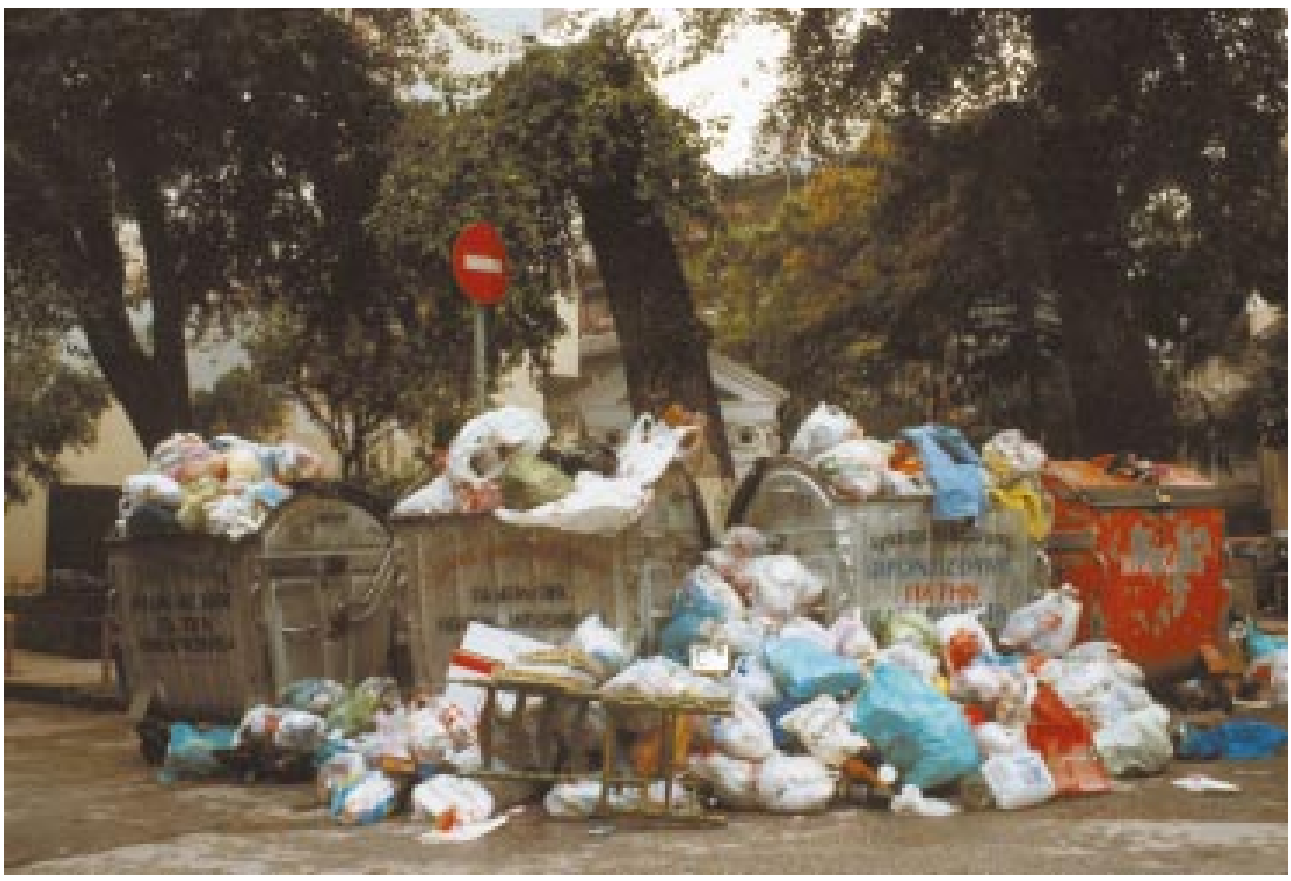

Figure 4 Piled up refuse during a 3-day strike of municipal workers in Greece (photograph: the author) 
within the homely was termed by Sigmund Freud as 'The Uncanny' [Unheimlich]. In his essay with the same title Freud notes that the German word 'heimlich' signifies the homely, the familiar (Freud, 1919: 342). However, 'heimlich' can also mean 'the concealed, what is kept from sight, withheld from others' (ibid.: 342-4). The linguistic opposite of 'heimlich', the word 'unheimlich' signifies the thing that 'ought to have remained secret and hidden but has come to light' (ibid.: 345). Thus, Freud makes the significant remark that 'heimlich is a word whose meaning develops in the direction of ambivalence, until it finally coincides with its opposite, unheimlich. Unheimlich is in some way or other a subspecies of heimlich' (ibid.: 345-7; original emphasis). It is precisely this familiar character of the heimlich, which produces the unheimlich effect when the former behaves in ways outside the ordinary, or when things that ought to have remained hidden come to light. Freud investigated cases where the heimlich becomes unheimlich, such as epileptic fits or manifestations of insanity, and argued that the 'uncanny' effect that such situations produce is due to the fact that these manifestations hint at processes that work and lie beyond what is the 'ordinary appearance' (ibid.: 347). It is when the predictable nature of the familiar acts in unpredictable ways that the uncanny effect is produced.

The haunted house is the most obvious and most cited spatial expression of the uncanny, a case of the manifestation of the unfamiliar within what is the most familiar environment. However, a building showing its 'guts', the networks that support its function, can produce a similar uncanny effect, a feeling of discomfort. Renzo Piano's and Richard Rogers' Pompidou centre in Paris (1972-76) is a good example of the uncanny effect produced by turning a building inside-out. The pipes, lines and cables of this building seemed to be 'out of place' when they unexpectedly appeared on its façade in 1976 (Silver, 1994). This appearance of typically hidden elements, although widely praised by 'informed' scholars and architects, was not originally equally appreciated by the Parisian public that remained perplexed for a while at the bold revelation of the building's guts.7 A more recent example is Rachel Whiteread's House (1993-94) a much cited installation in London's East End, comprising a full scale cast of the interior of a three storey terrace Victorian home scheduled for demolition. The installation unsettles the boundaries between inside/outside, open/closed and private/public space, thus producing an uncanny feeling to the viewer. Despite it being announced as temporary, the installation raised high levels of controversy, including the Bow Neighbourhood Committee demanding for it to be demolished (The Herald Magazine, 26 May 2003). Closer to the experience of the 'everyday', a disrupted domestic routine like a tap drying up, or even a dripping tap (Figure 5), a bursting pipe, or piled up refuse can produce a similar feeling of discomfort and anxiety, whereby 'one no longer feels at home in his most familiar environment' (Heidegger, cited in Wigley, 1996: 109). The surfacing of things that ought to remain hidden also undermines the air of familiarity that a home is supposed to exhale. The now famous design for the Dyson vacuum cleaner, which reveals rather than hides dirt and grime through a transparent cylinder, had to be marketed by the designer himself, since no company wished to manufacture it.

As Wigley (1996: 109) puts it:

through the systematic concealment of the uncanny in everyday life, the familiar is actually a mode of uncanniness. Just as alienation of modern life is not simply produced by the abyss underlying all structures but by the covering over of the abyss, it is equally produced by covering over the uncanniness behind and of the familiar.

One of the reasons why anxiety and discomfort is produced by a 'domestic network' crisis is precisely because it forces the dweller to reflect on the existence of social and economic relations to which the home is connected and which, when disrupted, render the 'normal' function of our lives anomalous. Such crises reveal that the familiarity based on the supposed autonomy of the private space is itself a form of alienation. It is 


\section{Ultra Annoying}

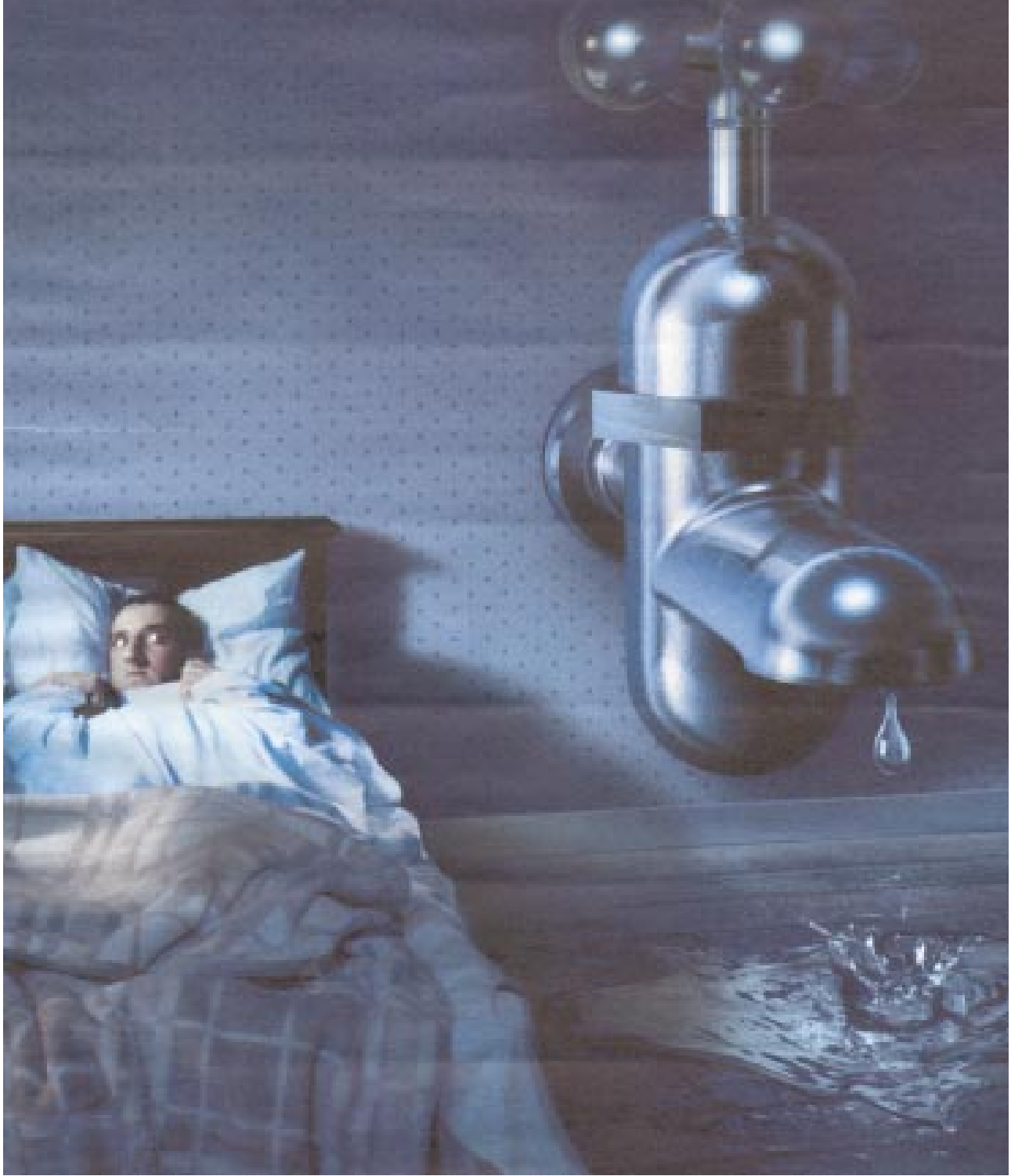

Figure 5 'Ultra Annoying': A tap which behaves unexpectedly produces the 'unhomely' within the comfort of one's own home (photograph by Erwin Olaf for cigarette advertisement in October 1999; reproduction courtesy of Erwin Olaf and M\&C Saatchi)

for this reason that Heidegger urges us to interrogate the familiar, since 'it carries an air of harmlessness and ease, which causes us to pass lightly over what really deserves to be questioned' (Heidegger, cited in Wigley, 1996: 109). Familiarity can veil the complex fabric of social and spatial relations involved in its own production, thereby assisting in the process of commodity fetishism. The familiarity of the domestic space conceals the 'violence' (in the form of social power relations) dwelling in the institutions, which make the construction and sustenance of any edifice possible. For example, the potential 'violence' of a tap dwells within the hands of the institutions who have the power to turn water supply on or off. By being unaware of this 'violence', by 
being trapped in a constructed domestic familiarity, we remain 'alienated' in the very space which is supposed to be the most familiar to us. The bourgeois home operates as a blissful private shelter insofar as it is selectively sealed from the world outside. One can be lost forever inside one's own painstakingly created familiarity, insofar as one is confined inside it. By eliminating (visually, perceptually and discursively-ideologically) the material connections and social relations that make its existence possible, the modern 'home' acquires the properties of both a refuge and a prison (Bachelard, 1948). The innocence of the familiar, if not interrogated, 'alienates by masking a more fundamental alienation: the obviousness and self-assurance of the average ways in which things have been interpreted as such' (Wigley, 1996: 109).

This form of alienation not only makes us prisoners of our own fears and needs, but also facilitates practices of exclusion. The supposedly undisputed imperative of maintaining public order and domestic bliss is often used as the main justification for political practices of exclusion: from the emergence of North American gated communities to the South African Apartheid regime, such practices are performed in the name of keeping social processes under control. But, in a stunningly similar manner, practices of social exclusion and political hegemony occur also in the name of keeping natural processes under control. For example, the process of burying urban rivers underground in the name of keeping bad nature away has been invariably connected to the clearance of the slums along the banks of urban rivers, and was, more often than not, hailed by the authorities as an 'inevitable' side effect of the necessary process of sanitizing urban space (Boyer, 1983; Gandy, 1999). This sanitization 'cleared' space for urban embourgeiosement (Sennett, 1994; Harvey, 1996) since it provided room for the 'free' movement of people, vehicles, goods and capital. This manipulation of patterns of urban social stratification in the name of controlling 'nature' is part of the history of most western metropoles. When the Seine (Zenne), in Brussels was covered during the nineteenth century, the settlements around its banks were swept away, giving way to what now constitutes the 'centre ville'. This process was glorified by the city's patrons, the king and the political elites, since the slums gave way to an emblematic example of nineteenth century bourgeois architecture. In the same way, the embankment of the Thames in London was part of the glorification of the British empire, while also contributing to what Oliver (2000: 229) refers to as 'cultural amnesia': a process which goes beyond just forgetting what a 'natural' river looks like (Cosgrove, 1990) and involves changing the actual perceptions of what the socio-natural urban landscape should look like. In Concrete and Clay, Gandy (2002) explores analogous practices in New York: the disappearance of New York's 'black' Seneca village in the name of creating 'nature' in the city under Olmstead's plans for the Central Park, or the practices of social exclusion hidden in the modernist designs of Robert Moses, the city's celebrated master planner. A similar process took place in Athens in the 1930s, when the 'sanitation' of the Illissos river resulted in the clearance of the illegal settlements along its banks, making room for the creation of one of the city's most expensive middle-class areas, all in the name of keeping nature under control (Tournikiotis, 1985; Papadakis, 1997).

Although the above examples are drawn from the early period of modernizing and rationalizing space in the western world, practices of social control and hegemony in the name of 'nature' are not confined to that historical period (high modernism) or to that geographical area (western world) only. Such practices are still present in the western and the developing world alike. In Flows of Power, Swyngedouw (2004; see also 1997) explores how in present-day Guayaquil, Ecuador, mechanisms of social exclusion ensure that water flows abundantly into private pools and water fountains inside the secluded, policed, private bourgeois homes, while $36 \%$ of the city's population lacks access to piped potable water. In the western world, such practices take place in a somewhat more sophisticated manner. Gandy (1997) interprets the recent introduction of environmental management technologies in New York, as a means of creating new investment opportunities for surplus capital. Along a similar vain, Nevarez (1996) investigates the case of Southern California, whereby public anxiety induced by rhetoric about the possibility of an imminent water crisis became a major political and 
economic tool for a consent-building exercise in favour of importing additional water supplies to the area. Kaika (2003) documents another example of similar practices linked to the (his)story of the drought experienced in Athens during the early 1990s, during which the water company decided to disrupt water supply. Suddenly, and unexpectedly, taps inside people's homes refused to provide their services as expected; they became a form of domestic uncanny: familiar objects which behaved in unfamiliar and disrupting ways. From being invisible and unproblematized, the connections between the house, the city and nature's water became the number one topic of media coverage and public awareness, a source of public anxiety and a threat to domestic bliss. The image and experience of pending disaster was accentuated by the water company's media campaign insisting that the spectre of drought announced the imminent death of the city from thirst. This threat and its careful nurturing, in turn, facilitated a specific set of policies: the decision to increase the price of water by up to $300 \%$ through a stratified price tariff which affected mostly the lower consumers and the Emergency Bill for the creation of a new dam project at Evinos River. The inhabitants of Athens, a city with a rather strong civil society accepted the policies in return for a promise that disruptions in water supply would stop. Moreover, the subsequent vilification of the public water company of Athens by part of the media, nurtured the view that the company was incapable of managing and controlling water resources efficiently, and paved the road for the company's privatization (see Kaika, 2003; 2004).

The above examples illustrate how the anxiety produced by the uncanny (interpreted as the manifestation of one's own alienation within one's familiar space) can be used as a political tool for the manipulation of public opinion and as a vehicle to push through specific political-economic agendas. The reason why the manifestation of the alienation within our most familiar environments assists in such political practices is exactly because the uncanniness is experienced as fear of loss of the safe and the sublime. As Sibley (1992: 245-6) contends, anxiety can be deepened by the creation of a false sense of security. If this holds true, then it would appear that the modernist enterprise to create binary distinctions and boundaries in order to do away with fear and anxiety actually served to deepen the very same problem it tried to eradicate. However, as we shall explore in the final part of this article, the unexpected surfacing of typically hidden elements, which brings to the foreground a recognition of the condition of alienation within the most familiar of environments, rather than being a source of fear and anxiety, has the potential to be a source of knowledge and emancipation.

\section{Interrogating the familiar: from anxiety to emancipation?}

We are nomads born, haptic creatures, and we spend our lives forgetting it. Architecture is the evidence of this denial ... We pile up stones feverishly in an attempt to reproduce the container, the vessel, the thing, producing the image at the expense of the voluptuous. We, like Sisyphus, never reach the goal because the impossibility of so doing is programmed into the rules of the game (Bloomer, 1993: 32).

Bloomer's assertion of the impossibility of constructing a familiar environment appears to be standing at the antipode of Ruskin's century older declaration of the feasibility of such an enterprise. Insofar as Ruskin's declaration echoes the optimism of the Enlightenment with respect to the possibility of doing away with human fear and alienation, Bloomer's quote echoes post-modernist pessimistic denial of the possibility to do so and acceptance of the condition of human alienation as an inevitable way of being. However, these two viewpoints share more in common than it might appear at first glance. For, although Bloomer appears to disagree with Ruskin about the possibility of achieving materially the 'voluptuous' in the form of the ideal familiar 'home', she nevertheless subscribes fully, along with Ruskin, to the sacredness of the platonic ideal-type of 'the home' as the sublime, 'the vessel', 'the container', and to the 
importance of trying to reproduce it. In fact, what Bloomer and Ruskin share in common is that they portray alienation and fear as the result of failing to produce materially this ideal-type, which remains sacred for both of them.

Somewhere between Enlightenment's optimism and post-modernist pessimism lie modernity's contradictory efforts to: a) construct a disconnected modern home and a disconnected modern individual within a world that becomes increasingly connected; and $b$ ) promote ideologically the disconnected private home as a sacred principle, while at the same time failing to produce it materially. Reflecting this contradiction, the modern home became simultaneously both the par excellence cultural sign of sublime modern living and its antipode: the par excellence cultural sign of the uncanny, of the alienation of the modern individual within his/her most familiar environment (Vidler, 1992). Indeed, in literature, art, media, film, etc. the home often features as the representation of the celebrated modernist dream of sublime western living; but it also functions as the paradigmatic cultural sign of the antipode of this dream: as the host of fear and anxiety. From Edgar Alan Poe's (1809-49) short stories, to Kafka's (18831924) Metamorphosis, to Harold Pinter's (1930-) Homecoming the home moves away from its role as a signifier of familiarity and bliss and becomes instead the emblematic representation of the uncanny. By putting one small detail of the familiar environment 'out of place' — yet still within the familiar domestic sphere — by revealing the contradictions and the uncanny qualities of modern living, nothing remains the same; the sublime, normalized character of modern dwelling is upset. In a similar manner, the unashamedly modernist movements of Dadaism and surrealism also disputed the sacredness and the sublime character of modern living and used the uncanny to replicate the individual's alienation within his/her own private space. Duchamp's ready made objects, included re-branding urinoirs as 'fountains' and displaying them on a pedestal as works of art; the Dadaist 'automatic poems' were a string of coherent words with correct syntax although with no apparent meaning; the Dadaist 'sound poems' a string of letters put together in a way that makes them look like words, although they are not (Ball, 1996; Richter, 1997; Huelsenbeck, 1998) (Figure 6); Magritte's series of paintings titled The Treachery of the Images (La Trahison des images) feature everyday objects in great representational detail, yet, a title above the object informs us that they are not what they seem. A photographic representation of a pipe is accompanied by a caption that informs us that 'ceci n'est pas une pipe'. Similarly, contrary to what we may think, Magritte informs us that a photographic representation of an apple should not be taken for granted since 'ceci n'est pas une pomme'. These works of art produced an effect of feeling unfamiliar and ill at ease with the most familiar objects, words, concepts and spaces. The subversive use of the uncanny in these movements aims at bringing the viewer/reader face to face with their alienation experienced within their most familiar environment and with their most familiar objects.

However, the modern home does not function only as a sign or a representation of the uncanny (Vidler, 1992: 12). Going beyond the contradiction between materiality and representation, between reality and the ideal type, this article illustrates that the dwelling places of modernity are hosts of the uncanny in their very structure. Once stripped of their well-constructed clarity and familiarity, or in moments of crisis, they are revealed as being themselves objects of surrealist art, pointing at the alienation of the dweller that inhabits them, subverting the image of the dwelling as the epitome of the familiar. In a simultaneous act of need and denial, they guard in their guts and in their underbelly everything they try to keep outside: sewerage, pipelines, dirt, rats, pests, crime, disease, the homeless.

Thus, questioning the familiarity of our most familiar environments can be an act of subversion in itself. Not only because it reveals the alienation within the familiar, but also because it undermines the belief in the possibility of producing a space that is totally disconnected from both social and natural processes. Questioning this belief becomes particularly important at a time when excess individualism has, at large, replaced civil action, and when the belief that 'no-one any longer has any alternatives to capitalism' (Giddens, 1998: 24, 43) has substituted imaginings of possibilities for 


\section{KARAWANE}

jolifanto bambla ô falli bambla grossiga m'pfa habla horem

égiga goramen

higo bloiko russula huju

hollaka hollala

anlogo bung

blago bung

blago bung

bosso fataka

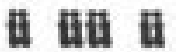

schampa wulla wussa ólobo

hej tatta gôrem

eschige zunbada

wulubu ssubudu uluw ssubudu

tumba ba- umf

kusagauma

ba - umf

Hugo Ball

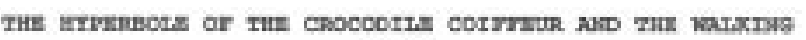
aรтcx

(Die Hyperbel vom

Krokodilcoiffeur und dem Sparier-etock]

se. Elmo' a fire zacess seund the beards of the anabsptiats

they poll their dary lamps from out of theis wayta

snd atiek their back sides in pudtites the sang, nail-durpling on pack-1ce

and mistled for her so sweetly round the corsur the slattern

that a casting-grate skidded

a eupenes on tour in Scandinavia aillorich blue crate ia a wrash hit

the tardiest aiskin mellingtons the groel pole

of a buttertag in pentas plunkge between the hair-erean of the gewer-man hair-raising foursey on the steep cliff

the bother emita a squamk

and falls dewn, perfectly, dead as tather's tcnshawk sinks into her bead

the chlldxen dafiee a raund, oft into the aunset.

the fatber otands, head bowed, ca the gun baat's peow

staggering-durb jackanandri11s someravult on nomalade belts ofe into the tea-set.

Viectheas rear eustcess office vowels full of qrizzliness

the olrcus-bating keel

would hang the profile

in the international cansis

sacranental-narshals

quartet-Mephistaphele

acanoing-acandala

Tristan Tarn, Waller Senter and Hass Arp (19

Figure 6 Left: Dadaist "Sound poetry": the uncanny in the language (author's interpretation of Hugo Ball's original play with the typescript); Right: Dadaist "Automatic poetry" 
human emancipation and of spaces where these possibilities can be fought for (see, among others, Lefebvre, 1974; the Situationists in Brandt, 1978 and Harvey, 2000). Exposing the dysfunctionality of the private spaces where blind individualism can be practised in isolation, calls for a reflection on alternative ways of engaging with the world. As Mary Douglas (1970) suggested, exploring the margins is important since it opens both destructive and creative possibilities. Exploring the uncanny materiality of 'the other' in the form of the invisible metabolized nature or technology networks points at the social construction of the separation between the natural and the social, the private and the public. It reveals 'the individual' 'the social' and 'the natural' as a socionatural continuum that disrupts the boundaries between the above socially constructed categories. Demonstrating the ideological construction of private spaces as autonomous and disconnected and insisting on their material and social connections calls for an end to individualization, fragmentation and disconnectedness that are looked for within the bliss of one's home. It calls for engaging in political and social action, which is, almost invariably, decidedly public.

Maria Kaika (maria.kaika@geog.ox.ac.uk), School of Geography and the Environment and St Edmund Hall, University of Oxford, Mansfield Road, Oxford OX1 3TB, UK.

\section{References}

Anderson, K. and J.M. Jacobs. (1999) Geographies of publicity and privacy: residential activism in Sydney in the 1970s. Environment and Planning A 31, 1017-30.

Bachelard, G. (1948) La terre et les rêveries $d u$ rèpos. Jose Corti, Paris.

Ball, H. (1996) Flight out of time: a Dada diary. E. John (ed.), University of California Press, Berkeley and London.

Bauman, Z. (1991) Modernity and ambivalence. Polity Press, Cambridge.

Bird, E. (1987) The social construction of nature: theoretical approaches to the history of environmental problems. Environmental Review 11, 260-71.

Bloomer, J. (1993) Architecture and the text: the (s)crypts of Joyce and Piranesi. Yale University Press, New Haven and London.

Boyer, C. (1983) Dreaming the rational city. MIT Press, Cambridge, MA.

Brandt, N. (1978) Revolutionary theory for beginners (pure and applied): three situationist texts. B.M. Combustion, London.

Braun, B. and N. Castree (1998) Remaking reality: nature at the millennium. Routledge, London.

Buisson, L. (1991) L'usage domestique de l'eau. Publications de l'École Moderne Francaise, Mouans-Sartoux.

Buck-Morss, S. (1995) The dialectics of seeing: Walter Benjamin and the Arcades Project. MIT Press, Cambridge, MA. Castree, N. (1995) The nature of produced International Journal of Urban and Regional Research nature: materiality and knowledge construction in Marxism. Antipode 27, 12-48.

Chappells, H., E. Shove and J. Selby (1999) Reservoirs, pipes and taps: a sociology of water, control and flow. Paper presented at a Conference on 'Sustainability, Risk and Nature: The Political Ecology of Water in Advanced Societies', School of Geography, University of Oxford, March.

Cleaver, F. and D. Elson (1995) Women and water resources: continued marginalisation and new policies. International Institute for Environment and Development, London.

Cosgrove, D. (1990) An elemental division: water, control and engineered landscape. In D. Cosgrove and G. Petts (eds.), Water, engineering and landscape: water control and landscape transformation in the modern period, Belhaven Press, London.

Curtis, V. (1986) Women and the transport of water. Intermediate Technology Publications, London.

Davis, M. (1992) Beyond Blade Runner: urban control - the ecology of fear. Vol. 23, Open Media, New Jersey.

Derrida, J. (1981) Dissemination. University of Chicago Press, Chicago.

- (1987) The postcard: From Socrates to Freud and beyond. University of Chicago Press, Chicago.

Deutsche, R. (1996) Evictions: art and spatial politics. The MIT Press, Cambridge, MA.

(C) Joint Editors and Blackwell Publishing Ltd 2004 
Douglas, M. (1970) Purity and danger: an analysis of concepts of pollution and taboo. Penguin, Harmondsworth.

Faust, D., H. Leitner, M.B.R. Nagar, E. Sheppard, B. Van Drasek and Y. Zhou (1992) Collective response: social justice, difference, and the city. Environment and Planning D: Society and Space 10, 589-95.

Fitzimmons, M. (1989) The matter of nature. Antipode 21, 106-20.

Forty, A. (1995) Objects of desire: design and society since 1750. Thames and Hudson, London.

Foucault, M. (1977) Discipline and punish: the birth of the prison. Penguin, Harmondsworth.

Freud, S. (1919) [1990] Art and literature. Vol. 14, Penguin, London.

Gandy, M. (1997) The making of a regulatory crisis: restructuring New York City's water supply. Transactions of the Institute of British Geographers 22, 338-58.

(1999) The Paris sewers and the rationalization of urban space.

Transactions of the Institute of British Geographers 24, 23-44.

- (2002) Concrete and clay: reworking nature in New York City. MIT Press, Cambridge, MA.

Gay, P. (1973) The Enlightenment: an interpretation: Vol 2: the science of freedom. Wildwood House, London.

Gerontas, D. and D. Skouzes (1963) To

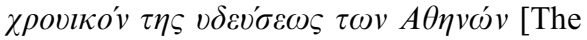
chronicle of watering Athens]. Athens.

Giddens, A. (1998) The third way: the renewal of social democracy. Polity Press, Cambridge.

Gilloch, G. (1996) Myth and metropolis. Polity Press, Cambridge.

Graham, S. and S. Marvin. (1996) Telecommunications and the city: electronic spaces, urban places. Routledge, London.

_ and S. Marvin (2001) Splintering urbanism. Routledge, London.

Grosz, E. (1995) Space, time and perversion. Routledge, London.

Halliday, S. (1999) The great stink of London: Sir Joseph Bazalgette and the cleansing of the Victorian metropolis. Sutton, Stroud.

Haraway, D. (1991) Simians, cyborgs and women - the reinvention of nature. Free Association Books, London.

Harvey, D. (1996) Justice, nature and the geography of difference. Blackwell, Oxford.
(2000) Spaces of hope. Edinburgh

University Press, Edinburgh.

and L. Chatterjee (1973) Absolute rent

and the structuring of space by

governmental and financial institutions.

Antipode 6, 22-36.

Hayford, A. (1974) The geography of women: an historical introduction. Antipode 6, 1-19.

Heidegger, M. (1962) Being and time. Blackwell, Oxford.

Hill, P. (1972) Rural Hausa: a village and a setting. Cambridge University Press, Cambridge.

Huelsenbeck, R. (1998) The Dada almanac. M. Green and A. Brotchie (eds.), Atlas Press, London.

Illich, I. (1986) $\mathrm{H}_{2} \mathrm{O}$ and the waters of forgetfulness. Marion Boyars, London.

Iordanidou, M. (1987) $\Sigma \tau o \nu \kappa \dot{\nu} \kappa \lambda o \nu \tau \alpha$ $\gamma \nu \rho i \sigma \mu \alpha \tau \alpha$ [The twirling of the circle]. Hestia, Athens.

Jacobs, J. (1961) The death and life of Great American cities. Random House, New York.

Kaika, M. (2003) Sensationalising water politics: 170 days that shook Athens. Antipode 35.5, 919-54. (2004) City of Flows. Routledge, New York.

and E. Swyngedouw (2000) Fetishizing the modern city: the phantasmagoria of urban technological networks. International Journal of Urban and Regional Research 24, 120-38.

Katz, C. (1998) Whose nature, whose culture? Private productions of space and the "preservation" of nature. In B. Braun and N. Castree (eds.), Remaking reality: nature at the millennium, Routledge, London. and A. Kirby (1991) In the nature of things: the environment and everyday life. Transactions of the Institute of British Geographers 16, 259-71.

Keil, R. (1998) Los Angeles: globalization, urbanization, and social struggles. John Wiley \& Son Ltd, New York.

Kellner, D. (1998) Zygmunt Bauman's postmodern turn. Theory, Culture, Society $15,73-86$.

Kendie, S.B. (1996) Some factors influencing effective utilization of drinking water facilities: women, income, and health in rural north Ghana. Environmental Management 20, 1-10.

Lahiji, N. and D.S. Friedman (1997) Plumbing: sounding modern architecture. 
Princeton Architectural Press, New York.

Latour, B. (1993) We have never been modern. Harvester Wheatsheaf, New York, London.

— and E. Hermant (1998) Paris ville invisible. La Decouverte, Paris.

Le Corbusier and J. Giraudoux (1933) [1957] La charte d'Athènes (IV International Congress for Modern Architecture. 1933: Athens, Greece). Éditions de Minuit, Paris.

Lefebvre, H. (1968) Le droit à la ville. Anthropos, Paris.

- (1974) [1994] The production of space. Blackwell, Oxford.

Lupton, E. and J.A. Miller (1996) The bathroom, the kitchen and the aesthetics of waste: a process of elimination. Kiosk (Princeton Architectural Press), New York.

Mackenzie, S. and G. Rose (1983) Industrial change, the domestic economy and home life. In J. Anderson, S. Duncan and R. Hudson (eds.), Redundant spaces in cities and regions, Academic Press, London.

Massey, D (1984) Spatial divisions of labour: social structures and the geography of production. Macmillan, London.

McDowell, L. (1983) Towards an understanding of the gender division of urban space. Environment and Planning D: Society and Space 1, 59-72.

Merrifield, A. (2000) The dialectics of dystopia: disorder and zero tolerance in the city. International Journal of Urban and Regional Research 24, 473-89.

Millett, K. (1977) Sexual politics. Virago, London.

Nevarez, L. (1996) Just wait until there's a drought: mediating environmental crises for urban growth. Antipode 28, 246-72.

Oliver, S. (2000) The Thames Embankment and the disciplining of nature in modernity. The Geographical Journal 166, 227-38.

Papadakis, M. (1997) Ilissos: the town's sacred river which disappeared. Technical Chamber of Greece, Athens.

Pile, S. (1996) The body and the city: psychoanalysis, space and subjectivity. Routledge, London.

Plato (1992) The Republic. Hackett, Indianapolis. (1995) Statesman. C.J. Rowe (ed.), Aris \& Phillips, Warminster.

Pollock, G. (1988) Vision and difference: femininity, feminism and the histories of art. Routledge, London.

Pratt, G. (1990) Feminist analyses of the restructuring of urban life. Urban Geography 11, 594-605.

Richter, H. (1997) Dada: art and anti-art. Thames and Hudson, London.

Rose, G. (1993) Feminism and geography: the limits of geographical knowledge. Polity Press, Cambridge.

Seager, J. (1997) The earth is not your mother. In L. Mcdowell and J. P. Sharp (eds.), Space, gender, knowledge: feminist readings, Arnold, London.

Sennett, R. (1990) The conscience of the eye: the design and social life of cities. Knopf, New York. (1994) Flesh and stone: the body and the city in Western civilization. Faber and Faber, London.

Shiva, V. (1997) Women in nature. In L. Mcdowell and J. P. Sharp (eds.), Space, gender, knowledge: feminist readings, Arnold, London.

Sibley, D. (1992) The binary city. Urban Studies 38, 239-50.

_ and G. Lowe (1992) Domestic space, modes of control and problem behaviour. Geografiska Annaler 74B, 189-98.

Silver, N. (1994) The making of Beaubourg: a building biography of the Centre Pompidou, Paris. MIT Press, Cambridge MA and London.

Simmons, I.G. (1993) Interpreting nature: cultural constructions of the environment. Routledge, London.

Smith, N. (1984) Uneven development: nature, capital and the production of space. Blackwell, Oxford.

Swyngedouw, E. (1997) Power, nature, and the city. The conquest of water and the political ecology of urbanization in Guayaquil, Ecuador: 1880-1990. Environment and Planning A 29, 311-32. (2004) Social power and the urbanisation of water: flows of power. Oxford University Press, Oxford. - and M. Kaika (2000) The environment of the city or ... the urbanisation of nature. In G. Bridge and S. Watson (eds.), A companion to the city, Blackwell, Oxford.

Tafuri, M. (1973) [1999] Architecture and utopia: design and capitalist development. MIT Press, Cambridge, MA.

Thacker, F.S. (1968) The Thames Highway. David and Charles, Newton Abbot.

Tournikiotis, P. (1985) Vassileos Konstantinou Avenue versus Ilissos: on 
the genealogy of urban form. In The Ministry of Culture and the Architectural Association of Greece (eds), Athens in the 20th century: Athens as it appears (not), 1940-1985, Athens.

Vidler, A. (1992) The architectural uncanny: essays in the modern unhomely. MIT Press, Cambridge, MA.

- (2001) Warped space: art, architecture and anxiety in modern culture. MIT Press, Cambridge, MA.
Wescoat, J.L. (1995) The 'right of thirst' for animals in Islamic law: a comparative approach. Environment and Planning D: Society and Space 13, 637-54.

Wigley, M. (1996) The architecture of deconstruction: Derrida's haunt. The MIT Press, Cambridge, MA.

Young, I.M. (1990) Throwing like a girl and other essays in feminist philosophy and social theory. University of Indiana Press, Bloomington. 